NASA TECHNICAL MEMORANDUM

$\frac{8}{x}$

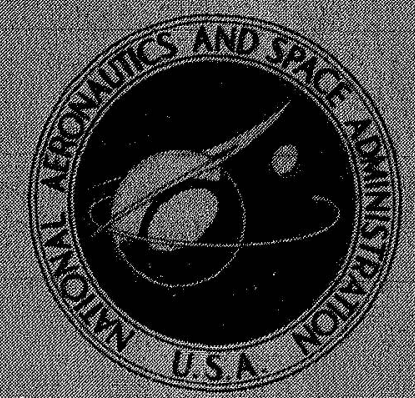

NASA TM X-1893

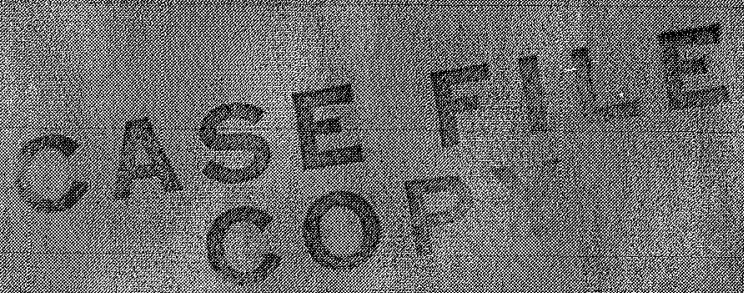

\title{
A SIMPLE METHOD FOR \\ DETERMINATION OF \\ FISSION GASES TRAPPED IN IRRADIATED FUEL FORMS
}

by Dean W. Sbeibley

Lewis Research Center

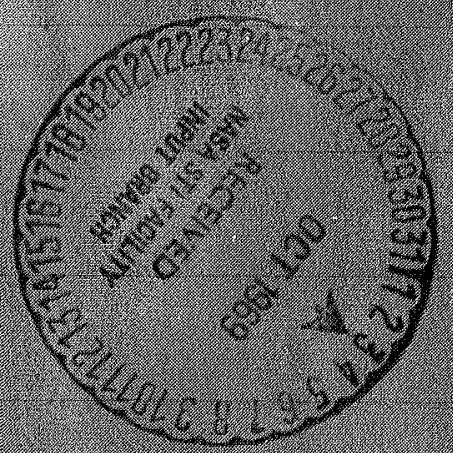

Cleveland, Obio

NATIONAL AERONAUTICS AND SPACE ADMINISTRATION - WASHINGTON, D. C, O OCTOBER 1969 


\title{
A SIMPLE METHOD FOR DETERMINATION OF FISSION GASES TRAPPED IN IRRADIATED FUEL FORMS
}

\author{
by Dean W. Sheibley \\ Lewis Research Center
}

\author{
SUMMARY
}

A simple, rapid, quantitative method is used for the determination of fission gases trapped in the cladding and matrix and in the fuel of irradiated molybdenum - uranium dioxide $\left(\mathrm{Mo}-\mathrm{UO}_{2}\right)$ and tungsten - uranium dioxide $\left(\mathrm{W}-\mathrm{UO}_{2}\right)$ fuel cermets. The method involves differential dissolution of the $\mathrm{Mo}$ or $\mathrm{W}$ and the $\mathrm{UO}_{2}$.

The gaseous activity is removed from the dissolution flask by flowing helium gas and is collected in special collection counting vials. The total gaseous activity is determined from the gas collection counting vials.

The technique requires only simple equipment. High vacuum systems and sophisticated methods of gas handling are not required. The method using the same basic equipment is adaptable for hot laboratory remote in-cell use. The explosion hazard resulting from electrolytic production of hydrogen and oxygen is eliminated.

The dissolution and gas trapping procedure requires from 1 to 2 hours for a 10 -gram specimen.

The accuracy of the method for determining krypton-85 $\left(\mathrm{Kr}^{85}\right)$ is \pm 2.5 percent (standard deviation) at $10^{8}$ disintegrations per minute. Recovery of activity from electrolytic or acid dissolution is greater than 99 percent.

\section{INTRODUCTION}

One objective of radiation damage studies on refractory-metal - uranium oxide cermets is to determine the ability of the fuel particles, the matrix, and the cladding to retain fission gases. Analyses of the irradiated fuel and refractory metal matrix and cladding for fission gas content are necessary in this evaluation.

A method used at Los Alamos (ref. 1) utilizes electrolytic dissolution of molybdenum cladding and matrix and acid dissolution of the fuel. A complex gas-trapping system utilizes a high-vacuum cold-trap pumping arrangement to transport the gases from the 
reaction flask to the gas collection can. An inherent hazard exists due to the presence of hydrogen and oxygen gases from electrolysis of the solution.

The method described in this report combines the differential dissolution technique with trapping of released fission gases on activated charcoal at liquid-nitrogen temperature. The hazard due to accumulation of hydrogen and oxygen generated from electrolysis of the solution is eliminated. The equipment and the procedure used for determining the gaseous activity by gamma counting are also described, and an evaluation of the method is presented.

\section{EXPERIMENTAL DETAILS}

\section{Equipment}

The equipment setup shown in figure 1 consists of a 2 -liter $\left(2 \times 10^{-3} \mathrm{cu} \mathrm{m}\right)$ vacuum flask, two drying tubes filled with silica gel, a manifold system containing a water trap maintained at liquid-nitrogen temperature, a 0 to 25 psia ( 0 to $1.72 \times 10^{5} \mathrm{~N} / \mathrm{m}^{2}$ abs) pressure transducer, and two gas-collection counting vials filled with activated charcoal and maintained at liquid-nitrogen temperature.

The 2 -liter $\left(2 \times 10^{-3}\right.$ cu $\left.\mathrm{m}\right)$ dissolution flask is a heavy-walled vacuum flask. The flask was hand blown with a round bottom to fit a heating mantle more easily. The flask was then pressure checked to 75 psig $\left(5.16 \times 10^{5} \mathrm{~N} / \mathrm{m}^{2}\right.$ gage) before use.

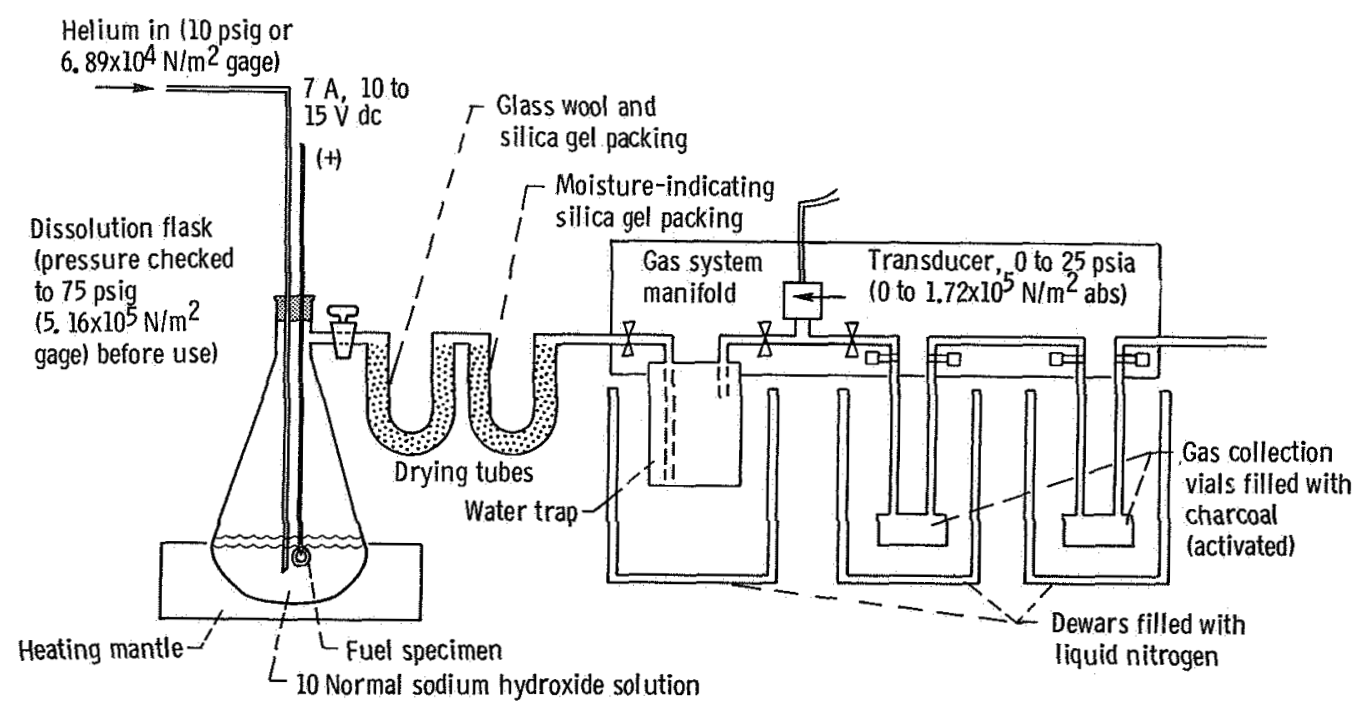

Figure 1. Fission gas collection system. 
The stopper used in the flask is specially fabricated of 6061-T6 aluminum. It is tapered to fit the inside neck of the flask. A rubber O-ring is inserted in a groove machined around the stopper. The stopper contains two electrodes which are insulated from each other and from the stopper by special fitted polytetrafluoroethylene (PTFE) plastic inserts. These inserts are placed into drilled and tapped holes in the stopper. The electrode-insert assembly is made leaktight by compression-type fittings which are drawn down onto the PTFE plastic insert. The electrode which holds the specimen is 304 stainless-steel welding rod with an alligator clip attached. The other electrode is a piece of 304 stainless-steel tubing into which a piece of platinum wire is silver soldered. Above this solder joint, several small holes are drilled into the electrode tube. This electrode serves a dual purpose since the helium sweep gas enters the system through it.

The complete stopper assembly is held in place by a double collar arrangement; one around the neck of the flask, the other on top of the stopper assembly. Two socket head bolts running through both collars are used to achieve a pressure- and vacuum-tight seal.

A modified stopper is used for the acid dissolution. It has two openings that provide for the helium gas inlet tube and the delivery tube of a separatory funnel that is inserted into a PTFE plastic sleeve which fits into the opening. A special top collar draws down on this insert to make the system leaktight.

Two drying tubes are attached in series to the side arm of the dissolution flask to collect moisture swept from the flask. The drying tubes are necessary to prevent the gas-collection vials from freezing. The drying tubes are followed by a stainless-steel water trap which is immersed in liquid nitrogen during dissolution. Two charcoal-filled gas-collection counting vials are connected in series. The entire system is swept with helium gas for 5 minutes before immersion in liquid nitrogen. The flow rate from the system is checked using a soap bubble flowmeter. A flow rate of 300 to 500 milliliters per minute $\left(5 \times 10^{-3}\right.$ to $\left.8.3 \times 10^{-3} \mathrm{cu} \mathrm{m} / \mathrm{sec}\right)$ is maintained. The inlet pressure is 5 to $10 \mathrm{psig}\left(3.45 \times 10^{4}\right.$ to $6.89 \times 10^{4} \mathrm{~N} / \mathrm{m}^{2}$ gage) of helium.

The gas-collection vials (fig. 2) are fabricated of 304 stainless steel and are of welded construction. The bottoms of the vials are 16-gage 304 stainless-steel plate. Each vial has two tubes; one for the gas inlet, the other for the gas outlet. The inner height of the chamber is 1 inch $(2.54 \mathrm{~cm})$. The interior of the vial is filled with charcoal. The pathway from the inlet tube to the outlet tube is made longer by five baffle plates: three welded to the bottom piece, two to the top. Each vial is pressure checked to $200 \mathrm{psig}\left(1.38 \times 10^{6} \mathrm{~N} / \mathrm{m}^{2}\right.$ gage) and vacuum checked. 


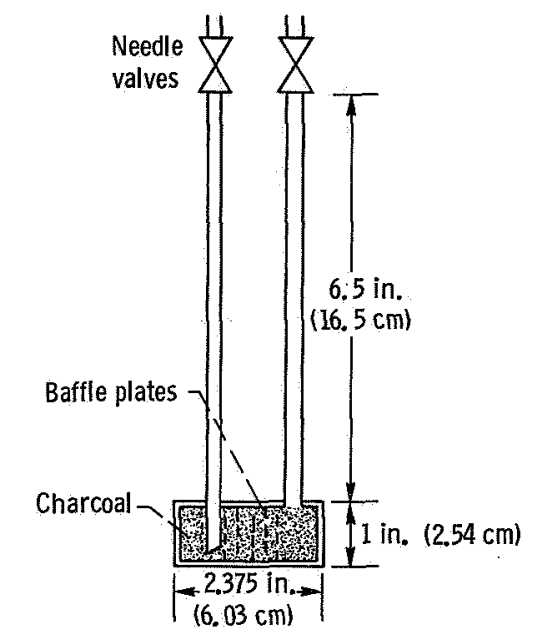

Figure 2 - Gas-collection counting vial. Bottom plate: 16-gage, 304 stainless steel; vial body: schedule 40 pipe.

\section{Gaseous Activity Determination}

The counting geometry factors for the gas-collection counting vials were determined for $\mathrm{Kr}^{85}$ in the following way: A gas-collection counting vial which did not contain charcoal was filled with a solution of gold-198 ( $\mathrm{Au}^{198}$ ) of known activity (This isotope was chosen since the $\gamma$ energy $0.41 \mathrm{MeV}$ is close to the $0.51 \mathrm{MeV} \gamma$ of $\mathrm{Kr}^{85}$ ). The vial was then gamma-counted at various distances above a 3 - by 3 -inch $(7.62-$ by $7.62-\mathrm{cm}$ ) $\mathrm{Na}(\mathrm{Tl}) \mathrm{I}$ crystal. The crystal was coupled to a 512 -channel gamma-ray spectrometer. From the disintegration rate known to be in the vial and the count rate obtained, factors for the various distances were obtained to convert counts to disintegrations. The factors for the vial (from $\mathrm{Au}^{198}$ ) were then corrected to give the $\mathrm{Kr}^{85}$ disintegration rate by multiplying the disintegration rate of $\mathrm{Au}^{198}$ by the ratio of $\mathrm{Kr}^{85} / \mathrm{Au}^{198}$ known geometry factors.

The accuracy and efficiency of gaseous activity recovery were checked for the electrolytic and acid dissolution methods. A gas-collection counting vial containing $\mathrm{Kr}^{85}$ fission gas was counted and the total disintegrations per minute determined. This vial was then connected to the negative electrode tube and the fission gas was swept by helium purge into the reaction vessel during dissolution of dummy specimens. The fission gas was recovered by counting the two gas-collection counting vials when dissolution was complete. The first vial in the series always contained $99^{+}$percent of the fission gas used. The second vial showed less than 1 percent of the original gaseous activity. 
The same techniques could be applied to determine counting factors and recovery efficiencies for other radioactive gaseous fission products, such as xenon-133 (Xe ${ }^{133}$ ) and xenon-135 $\left(\mathrm{Xe}^{135}\right)$. Factors for these isotopes were not necessary in this work since several months elapsed from the end of irradiation to sample processing.

\section{Procedure}

An alligator clip attached to the positive electrode of the dissolving flask holds a piece of the $\mathrm{Mo}-\mathrm{UO}_{2}$ or $\mathrm{W}-\mathrm{UO}_{2}$ cermet, as shown in figure 1. The negative electrode also serves as the helium gas inlet to the sample container. Approximately 60 milliliters $\left(6 \times 10^{-5} \mathrm{cu} \mathrm{m}\right)$ of 10 normal $\mathrm{NaOH}$ per 10 grams of sample are placed in the dissolving flask. The two gas-collection vials are placed in series and evacuated. The entire system is checked for leaks under vacuum and again when pressurized with helium. A 0 to 25 psia ( 0 to $1.72 \times 10^{5} \mathrm{~N} / \mathrm{m}^{2}$ abs) transducer is used to monitor pressures. The entire system is swept with helium for 5 minutes before use.

Liquid nitrogen is placed in the Dewars to cool the water trap and gas-collection vials. The water trap is preceded by two drying tuoes; one packed with glass wool and silica gel, and the other charged with moisture-indicating silica gel. The traps immersed in liquid nitrogen are allowed to cool for 15 minutes before using.

The power leads are then attached to the electrodes and a direct current of 5 to 7 amperes is applied at 10 to 15 volts. Helium sweeps through the system at a rate of approximately 300 to 500 milliliters per minute $\left(5 \times 10^{-3}\right.$ to $\left.8.3 \times 10^{-3} \mathrm{cu} \mathrm{m} / \mathrm{sec}\right)$. The Mo or $\mathrm{W}$ dissolves and the $\mathrm{UO}_{2}$ drops to the bottom of the flask. The hydrogen and oxygen produced from electrolysis of the solution are diluted by the helium gas and are swept from the system. Complete dissolution of the cladding and matrix on a 10-gram $\left(1 \times 10^{-2}-\mathrm{kg}\right)$ specimen requires 1 to 2 hours. The dissolution is started with only about half the specimen immersed. As required, the specimen is moved into the solution by gently pushing the electrode down. The entire specimen is dissolved by finally immersing the tip of the alligator clip holding the specimen.

After dissolution is completed, the helium sweeping is continued for another 15 minutes. During the electrolysis, enough heat is generated so that heating the solution is not necessary.

The gas collection counting vials are removed from the liquid nitrogen and allowed to warm to room temperature. Then the vials are gamma counted for $\mathrm{Kr}^{85}$.

The solution remaining in the flask is decanted carefully so that the $\mathrm{UO}_{2}$ is left in the flask. Again the flask is placed in the heating mantle. The system is leak checked and two new gas collection vials are placed in the Dewars. A vacuum is drawn on the 
vials. The liquid nitrogen is added to the Dewars. The gas-collection vials are cooled in liquid nitrogen for 15 minutes before use.

The system is purged with helium at 300 to 500 milliliters per minute $\left(5 \times 10^{-3}\right.$ to $\left.8.3 \times 10^{-3} \mathrm{cu} \mathrm{m} / \mathrm{sec}\right)$. Then a slight vacuum is pulled on the system. Sixty milliliters $\left(6 \times 10^{-5}\right.$ cu $\left.\mathrm{m}\right)$ of 50 volume percent nitric acid +50 volume percent hydrochloric acid is placed in a separatory funnel above the flask and added slowly to the flask (the modified stopper for the flask is required for this phase). Heat is applied to the flask from the heating mantle. The dissolution of the $\mathrm{UO}_{2}$ takes approximately 1 hour. After the dissolution is completed, the helium purge is continued for an additional 15 minutes. The gas-collection vials are removed and allowed to warm to room temperature. They are gamma counted for $\mathrm{Kr}^{85}$. The resulting fuel solutions can be analyzed for cesium-137 $\left(\mathrm{Cs}^{137}\right)$, strontium $-90\left(\mathrm{Sr}^{90}\right)$, and uranium, using ASTM methods or standard radiochemical procedures.

\section{Evaluation of Experimental Results}

The accuracy of the method for determining $\mathrm{Kr}^{85}$ activity including the counting error is \pm 2.5 percent (standard deviation) at $10^{8}$ disintegrations per minute. The range of $\mathrm{Kr}^{85}$ activity which can be handled with the counting system described, and at the same accuracy, is 5 microcuries to 100 millicuries $\left(1.9 \times 10^{5}\right.$ to $\left.3.7 \times 10^{9} \mathrm{dis} / \mathrm{sec}\right)$.

The $\mathrm{Kr}^{85}$ gas activity data are used with the uranium burnup information to determine the relative effectiveness of the cermet cladding for fission gas retention. Based on the fuel burnup data of the specimens analyzed, the amount of $\mathrm{Kr}^{85}$ produced during irradiation can be calculated. A material balance on $\mathrm{Kr}^{85}$ is made by combining the activities found in the fuel and the activity in the cladding and matrix with the activity found outside the fuel form. (The $\mathrm{Kr}^{85}$ activity outside the fuel form is determined in a separate remote in-cell puncturing operation on the experiment containment vessel.) Material balances obtained have been reasonable. Similar operations are reported in reference 2. However, only portions of the fuel form, and not the entire fuel form, have been analyzed with this method. Therefore, it is not possible to assign an overall accuracy to the method.

\section{Lewis Research Center,}

National Aeronautics and Space Administration, Cleveland, Ohio, August 1, 1969, 120-27. 


\section{REFERENCES}

1. Patrick, A. J.: Gas-Collection Technique for Measurement of Fission-Gas Retention in Ir radiated Mo-UO 2 Cermets. Rep. LA-3718, Los Alamos Scientific Lab., May 17, 1967.

2. Seffert, D. A.; Stuart, R. L.; Conn, P. K.; McLaughlin, H. W.; and Luersen, G. J.: Fission Product Behavior Within Two W-Uranium Dioxide Cermet FueI Elements Irradiated in a Temperature Gradient. Rep. GEMP-635, General Electric Co., Aug. 1968. 


\begin{tabular}{|c|c|c|c|c|c|}
\hline & $\begin{array}{l}\text { Report No. } \\
\text { NASA TM X-1893 }\end{array}$ & \multicolumn{2}{|c|}{ 2. Government Accession No. } & \multicolumn{2}{|c|}{ 3. Recipient's Catalog No. } \\
\hline & \multirow{2}{*}{\multicolumn{3}{|c|}{$\begin{array}{l}\text { Title and Subtitle } \\
\text { A SIMPLE METHOD FOR DETERMINATION OF FIS- } \\
\text { SION GASES TRAPPED IN IRRADIATED FUEL FORMS }\end{array}$}} & \multicolumn{2}{|l|}{$\begin{array}{l}\text { 5. Report Date } \\
\text { October } 1969\end{array}$} \\
\hline & & & & \multicolumn{2}{|c|}{ 6. Performing Organization Code } \\
\hline & \multicolumn{3}{|l|}{$\begin{array}{l}\text { Author(s) } \\
\text { Dean W. Sheibley }\end{array}$} & \multicolumn{2}{|c|}{$\begin{array}{l}\text { 8. Performing Organization Report No. } \\
E-5167\end{array}$} \\
\hline & \multirow{3}{*}{\multicolumn{3}{|c|}{$\begin{array}{l}\text { Performing Organization Name and Address } \\
\text { Lewis Research Center } \\
\text { National Aeronautics and Space Administration } \\
\text { Cleveland, Ohio } 44135\end{array}$}} & \multicolumn{2}{|c|}{$\begin{array}{l}\text { 10. Work Unit No. } \\
120-27 \\
\end{array}$} \\
\hline & & & & \multicolumn{2}{|c|}{ 11. Contract or Grant No. } \\
\hline & & & & \multirow{2}{*}{\multicolumn{2}{|c|}{$\begin{array}{l}\text { 13. Type of Report and Period Covered } \\
\text { Technical Memorandum }\end{array}$}} \\
\hline & \multirow{2}{*}{\multicolumn{3}{|c|}{$\begin{array}{l}\text { Sponsoring Agency Name and Address } \\
\text { National Aeronautics and Space Administration } \\
\text { Washington, D. C. } 20546\end{array}$}} & & \\
\hline & & & & \multicolumn{2}{|c|}{ 14. Sponsoring Agency Code } \\
\hline \multicolumn{6}{|c|}{ 15. Supplementary Notes } \\
\hline & \multicolumn{5}{|c|}{$\begin{array}{l}\text { Abstract } \\
\text { A simple, rapid, safe, quantitative method for determining fission gases trapped in } \\
\text { of the cladding and matrix, and acid dissolution of the fuel. The gaseous activity is } \\
\text { collected in charcoal collection vials at liquid-nitrogen temperature. Recovery is } \\
\text { greater than } 99 \text { percent. Fission gas activity is determined by gamma-counting the } \\
\text { gas-collection vials. The explosion hazard due to the electrolytic production of } \\
\text { hydrogen and oxygen is eliminated. The accuracy of the method is } \pm 2.5 \text { percent } \\
\text { (standard deviation) at } 10^{8} \text { disintegrations per minute. }\end{array}$} \\
\hline & \multicolumn{2}{|c|}{$\begin{array}{l}\text { Key Words (Sugkested by A uthor(s)) } \\
\text { Fission gas determination }\end{array}$} & \multicolumn{3}{|c|}{$\begin{array}{l}\text { 18. Distribution Statement } \\
\text { Unclassified - unlimited }\end{array}$} \\
\hline \multicolumn{2}{|r|}{$\begin{array}{c}\text { 19. Security Classif. (of this report) } \\
\text { Unclassified }\end{array}$} & \multicolumn{2}{|c|}{$\begin{array}{l}\text { 20. Security Classif. (of this poge) } \\
\text { Unclassified }\end{array}$} & $\begin{array}{c}\text { 21. No. of Pages } \\
8\end{array}$ & $\begin{array}{l}\text { 22. Price* } \\
\$ 3.00\end{array}$ \\
\hline
\end{tabular}

*For sale by the Clearinghouse for Federal Scientific and Technical Information Springfield, Virginia 22151 


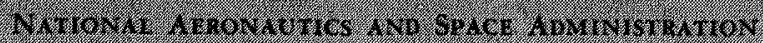

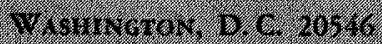

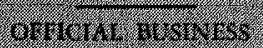

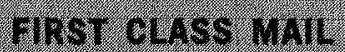

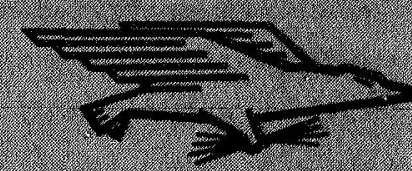

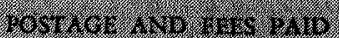

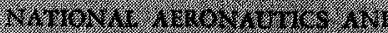

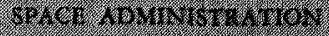

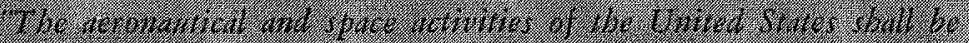

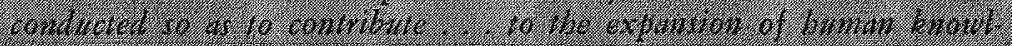

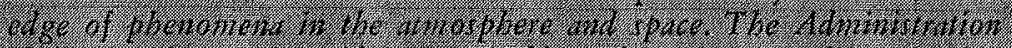

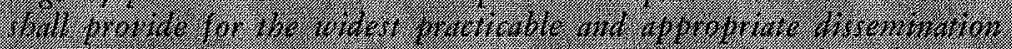

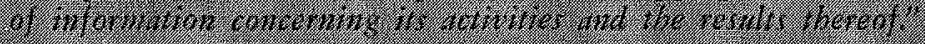

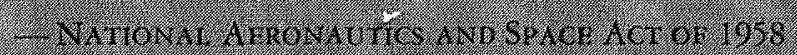

\section{NASA SGIENTIFIC AND TECHNICAL PUBIICATIONS}

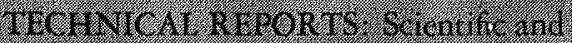

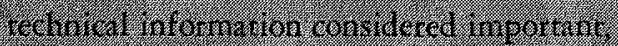
complete. and insting contribution to exristing lnometise.

TECHNICAT NOTES: Information less, broud in scope but neverticless of inportince is d

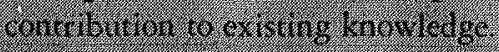

\section{TECHNICA I TMMOR ANDUMS:}

Information receiving Imitce distribution

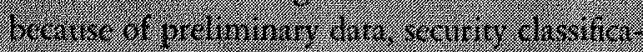
thot. or nther tersons.

\section{CONTRACTOR RERON TS Scientfe and}

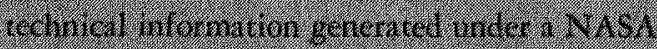
cinmace or grimt and consitered in importurt

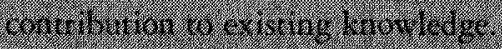

TECHNICAN TRANSI ATIONS: Information

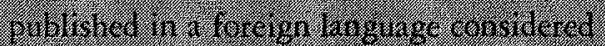
to ment NASA arsmbitrion in Im glish.

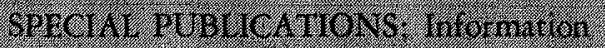
derived from of of value to NASA activities. Publications: inclurle confertente procededings: monographs, data complation. hantbooks. soircebooks, ardi spechil bibliographies.

\section{TRCMNOLOCX UTIZATION.}

PCDLIC ATIONS: Information on rechndogt ised by NASA that may beof tarcicution

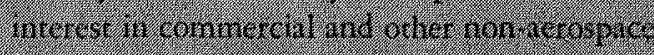
4pultcations. Pablications include Teth Briefs:

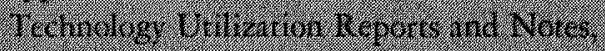
and Terinklosy Sheress:

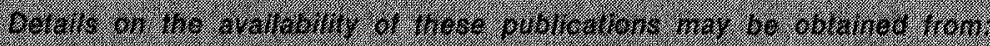

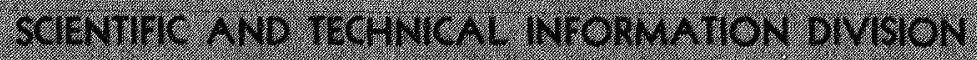

NATIONAL AERONAUTICS AND SPACE ADMINISTRATION

Wathington, D.C. 20546 